\title{
REVITALIZATION BMT AND COOPERATIVES FUNCTION IN DEVELOPING SYARI'AH ECONOMY
}

\author{
Ach Baihaki *)
}

\begin{abstract}
The growth of islamic economics have been more improvement, as in infrastructure, assets and number of employee year of the year. But by that improvement, there are some problems to be payed attention, like development of quality of human resources in Islamic economics system with holistic approach. So that, to strengthen the character of Islamic economics system need to restore it's concept to the nature of Islamic thought consider with the Islamic economics history and also accommodate local wisdom. To support the improvement of Islamic economics proper with ideology objectives of islam, cooperation and BMT should be have priority to increase their functions and responsibilities in economics development. Operational of cooperation and BMT will make variability of Islamic contracts more variative. Then Islamic contract by partnership approach based profit and losses sharing will have more proportions and cost of control also will be more efficient and worries about information asymmetry will be declined. It caused, awareness of partnership and togetherness to increase cooperation member welfare will be easily achived.
\end{abstract}

Keywords: Business Entity, Islamic Financial Institutions, Cooperation, BMT

\section{PENDAHULUAN}

\subsection{Latar Belakang}

Lahirnya kajian tentang ekonomi syari'ah yang berlandaskan nilai-nilai keislaman awalnya menjadi sebuah bahan tertawaan orang lain (Harahap, 2001:12). Karena memang tidak bisa dipungkiri hegemoni sistem perekonomian kapitalis dan sosialis sangat mempengaruhi pemikiran dan pola praktek perekonomian suatu negara hingga pada akhirnya sistem ekonomi sosialis runtuh dan yang menjadi pesaing ideologi utama kapitalis adalah islam. Lahirnya lembaga keuangan syari'ah yang pertama di Mesir pada tahun 1963 juga menjadi momentum awal tumbuh kembangnya perekonomian islam pada zaman kontemporer ini.

Meskipun sistem ekonomi syari'ah masih baru berkembang beberapa dekade terakhir ini dengan bermunculannya lembaga keuangan syari'ah baik mikro, kecil, menengah ataupun korporasi dengan segala bentuk instrumen layanan keuangan yang diberikan. Akan tetapi sebenarnya perekonomian syari'ah telah ada sejak zaman awal kemunculan islam yang ditandai dengan lembaga Baitul Maal yang menjadi lembaga central dalam tata kelola keuangan negara yang sesuai dengan kaidah ajaran islam. Disamping itu seperangkat tata etika pengelolaan perekonomian telah berkembang baik dan telah diajarkan secara sempurna oleh Rasulullah. SAW semasa hidupnya.

Sehingga pertumbuhan lembaga keuangan syari'ah beberapa akhir ini juga bukan merupakan hal yang baru dalam dunia islam. Akan tetapi yang perlu menjadi perhatian adalah perkembangan lembaga keuangan syari'ah ini yang telah menjadi pendorong munculnya kajian dan aplikasi perekonomian berbasis islam ini akan menjadi sebuah bumerang nantinya. Karena kemunculan instrumen pembiayaan dan pendanaan syari'ah dan bahkan lembaga keuangan syari'ah ini jangan sampai menghilangkan citacita luhur dari nilai-nilai ajaran islam dalam bidang ekonomi yang berbasis tolong menolong dan kesejahteraan ummat.

Kekhawatiran ini menjadi perlu mendapatkan perhatian serius. karena perkembangan minat masyarakat untuk menggunakan lembaga jasa keuangan syari'ah, baik funding maupun lending akhir ini hanya akan menjadi target pasar dalam dunia bisnis bagi beberapa lembaga keuangan yang hanya mengandalkan orientasi tata kelola organisasinya pada profit oriented. Hal ini terbukti dengan bermunculannya berbagai lembaga keuangan yang sedari awal berbasis konventional dan profit oriented semata juga mengembangkan usahanya pada sektor syari'ah. Peningkatan jumlah entitas dari sisi jumlah kantor dan sumber daya manusia untuk meningkatkan layanannya dapat diperhatikan dalam tabel 1. 
Berdasarkan data pada tabel 1 tersebut, jika tahun 2010 dijadikan tahun dasar, maka pertumbuhan jumlah kantor sebagai bentuk pertumbuhan lembaga keuangan syari'ah yang juga menjadi indikator berkembangnya sistem perekonomian syari'ah menjadi sesuatu yang menggembirakan. Akan tetapi pada proses selanjutnya, bagaimana perkembangan ini tidak hanya dari sisi kuantitas jumlah kantor layanan dan SDM yang melayani. Akan tetapi perkembangan ini juga diikuti oleh peningkatan kualitas aplikasi pelayanan lembaga keuangan syari'ah tersebut yang tidak meninggalkan tujuan dari penerapan ekonomi syari'ah tersebut.

Karena berdasarkan penerapan akad dalam lembaga keuangan syari'ah masih bertumpu pada pembiayaan yang mendekati skema kredit pada lembaga konvensional dengan pola keuntungan atas pembiayaan yang diberikan kepada nasabah bersifat tetap. Sehingga kadang kala masih sering muncul pertanyaan secara umum di masyarakat tentang "apakah bedanya antara konvensional dengan syari'ah?". Hal ini menjadi ironis, karena seharusnya akad pembiayaan yang menjadi ciri khas lembaga keuangan syari'ah masih belum menempati prioritas jenis pembiayaan yang ditawarkan lembaga keuangan syari'ah. Hal lain yang menarik untuk menjadi perhatian dalam pengembangan perekonomian syari'ah adalah sektor usaha mikro dan mikro yang berbasis ekonomi masyarakat akar rumput masih menjadi perhatian kecil lembaga keuangan perbankan syari'ah. Padahal secara ketersediaan modal kerja yang bisa disalurkan kepada masyarakat jauh lebih besar dibandingkan dengan lembaga keuangan mikro syari'ah. Data yang berkaitan dengan pembiayaan yang ditawarkan oleh perbankan syari'ah Indonesia tersaji dalam tabel 2 dan tabel 3.

Tabel 1 Jumlah kantor dan SDM Bank Syari'ah

\begin{tabular}{|c|c|c|c|c|c|c|c|c|c|c|}
\hline \multirow{2}{*}{$\begin{array}{l}\text { Jenis } \\
\text { Bank }\end{array}$} & \multicolumn{2}{|c|}{2010} & \multicolumn{2}{|c|}{2012} & \multicolumn{2}{|c|}{2013} & \multicolumn{2}{|c|}{2014} & \multicolumn{2}{|c|}{ Apr-15 } \\
\hline & Absolut & Pertumbuhan & Absolut & Pertumbuhan & Absolut & Pertumbuhan & Absolut & Pertumbuhan & Absolut & Pertumbuhan \\
\hline \multicolumn{11}{|c|}{ Jumlah Kantor } \\
\hline BUS & 1215 & $100 \%$ & 1745 & $144 \%$ & 1998 & $164 \%$ & 2151 & $177 \%$ & 2135 & $176 \%$ \\
\hline UUS & 262 & $100 \%$ & 517 & $197 \%$ & 590 & $225 \%$ & 320 & $122 \%$ & 323 & $123 \%$ \\
\hline BPRS & 286 & $100 \%$ & 401 & $140 \%$ & 402 & $141 \%$ & 439 & $153 \%$ & 433 & $151 \%$ \\
\hline \multicolumn{11}{|c|}{ Jumlah Karyawan } \\
\hline BUS & 15224 & $100 \%$ & 24111 & $158 \%$ & 26717 & $175 \%$ & 41393 & $272 \%$ & 49587 & $326 \%$ \\
\hline UUS & 1868 & $100 \%$ & 3108 & $166 \%$ & 11511 & $616 \%$ & 4425 & $237 \%$ & 4404 & $236 \%$ \\
\hline BPRS & 3172 & $100 \%$ & 4559 & $144 \%$ & 4826 & $152 \%$ & 4704 & $148 \%$ & 5000 & $158 \%$ \\
\hline
\end{tabular}

\section{Sumber: Statistik OJK RI ${ }^{1}$}

Berdasarkan data pada tabel 2 dan 3 tersebut diketahui bahwa akad yang menjadi dasar pembeda antara praktek keuangan lembaga keuangan konvensional yang berbasis bunga dengan praktek keuangan syari'ah yang seharusnya berbasis profit and losses sharing (PLS) masih belum kelihatan signifikan. Berdasarkan tabel tersebut diatas bank umum syari'ah (BUS) dan unit usaha syari'ah (UUS) masih mengalokasikan pembiayaannya kepada pembiayaan yang berbasis PLS sebanyak 33\%, sedangkan $58,33 \%$ berbasis margin dengan pembayaran keuntungan bagi lembaga keuangan bersifat tetap dan sisanya berbasis fee. Sedangkan BPRS yang memiliki cakupan operasional lebih sempit dibandingkan dengan BUS dan UUS justru mengalokasikan pembiayaan kepada akad pembiayaan yang berbasis margin sebesar 79,35\% dari total pembiayaannya. Padahal jika BPRS berkeinginan untuk bermitra dengan nasabah yang minus dana, pengawasan atas kerja samanya tersebut bisa lebih optimal, karena kedekatan terirorial operasional antara lembaga keuangan syari'ah dengan nasabah pembiayaannya.

\footnotetext{
${ }^{1}$ http://www.ojk.go.id/data-statistik-perbankan-syariah /diakses tanggal 5 Oktober 2015.
} 
Tabel 2: Pembiayaan BUS dan UUS

Per: April 2015 (dalam miliar rupiah)

\begin{tabular}{|l|r|r|}
\hline \multicolumn{1}{|c|}{$\begin{array}{c}\text { Jenis } \\
\text { Pembiayaan }\end{array}$} & Jumlah & Persentase \\
\hline \hline Akad Mudharabah & 14388 & $7 \%$ \\
\hline Akad Musyarakah & 52672 & $26 \%$ \\
\hline Akad Murabahah & 117210 & $58 \%$ \\
\hline Akad Salam & 0 & $0 \%$ \\
\hline Akad Istishna' & 664 & $0.0033 \%$ \\
\hline Akad Ijarah & 11454 & $6 \%$ \\
\hline Akad Qardh & 5138 & $3 \%$ \\
\hline Akad Lainnya & & $0 \%$ \\
\hline Total & $\mathbf{2 0 1 5 2 6}$ & $\mathbf{1 0 0 \%}$ \\
\hline
\end{tabular}

Tabel 3: Pembiayaan BPRS

Per: April 2015 (dalam Jutaan rupiah)

\begin{tabular}{|l|r|r|}
\hline \multicolumn{1}{|c|}{$\begin{array}{c}\text { Jenis } \\
\text { Pembiayaan }\end{array}$} & Jumlah & Persentase \\
\hline \hline Akad Mudharabah & 133805 & $3 \%$ \\
\hline Akad Musyarakah & 582366 & $11 \%$ \\
\hline Akad Murabahah & 4212147 & $79 \%$ \\
\hline Akad Salam & 16 & $0.0003 \%$ \\
\hline Akad Istishna' & 12059 & $0.2264 \%$ \\
\hline Akad Ijarah & 6614 & $0.1242 \%$ \\
\hline Akad Qardh & 108523 & $2 \%$ \\
\hline Akad Lainnya & 270571 & $5 \%$ \\
\hline Total & $\mathbf{5 3 2 6 1 0 1}$ & $\mathbf{1 0 0 \%}$ \\
\hline
\end{tabular}

Sumber: Statistik OJK RI ${ }^{2}$

Selain itu yang perlu menjadi perhatian adalah bagaimana lembaga keuangan syari'ah yang berbasis korporasi tersebut diatas memberikan pembiayaan terhadap sektor-sektor perekonomian di Indonesia. Karena sektor perekonomian yang menjadi prioritas pembiayaan lembaga keuangan tersebut akan menunjukkan komitmennya dalam mewujudkan kesejahteraan masyarakat. Adapun penyaluran pembiayaan berdasarkan sektor ekonomi oleh bank umum syari'ah dan unit usaha syari'ah bisa diperhatikan pada tabel 4 serta oleh BPRS pada tabel 5.

Berdasarkan data tersebut, maka jumlah pembiayaan yang dialokasikan kepada sektor pertanian dari seluruh sektor ekonomi hanyalah 3\% oleh bank umum syari'ah dan unit usaha syari'ah, sementara itu 5\% disalurkan oleh BPRS dari seluruh total pembiayaannya. Sementara itu masyarakat Indonesia menurut sumber Biro Pusat Statistik pada tahun 2013 memiliki masyarakat yang bekerja di sektor pertanian sebanyak 31.705.337 orang. Jika lembaga keuangan syari'ah tidak hanya memperhatikan profitabilitas semata, akan tetapi juga proses pemberdayaan masyarakat, maka pengembangan perekonomian masyarakat mikro juga akan menjadi lebih baik.

Lembaga keuangan tidak hanya akan menjadi lembaga intermediasi keuangan yang akan menjembatani masyarakat surplus dana kepada masyarakat minus dana sehingga perekonomian nasional akan menjadi lebih baik lagi. Tapi juga lembaga keuangan syai'ah khususnya juga akan menjadi lembaga yang efektif dalam mengurangi kesenjangan kesejahteraan sosial di dalam masyarakat. Atas kesenjangan ketercapaian visi dan misi dari pengembangan ekonomi syari'ah tersebut, bahkan pembiayaan lembaga keuangan syari'ah yang berbasis Profit and Losses Sharing Malaysia yang terkenal sebagai salah satu kiblat perekonomian islam dunia pada akhir tahun 2004 hanya sebesar 0,5\% (Chong dan Liu, 2009:133).

\subsection{Permasalahan Penelitian}

Berdasarkan deskripsi latar belakang tersebut permasalahan penelitian yang diajukan adalah bagaimanakah revitalisasi Koperasi dan BMT dalam pengembangan ekonomi berbasis syariah.

\subsection{Tujuan Penelitian}

Adapun tujuan dilakukan penelitian ini adalah untuk mengetahui bagaimanakah revitalisasi Koperasi dan BMT dalam pengembangan ekonomi berbasis syariah,

\footnotetext{
${ }^{2}$ http://www.ojk.go.id/data-statistik-perbankan-syariah /diakses tanggal 5 Oktober 2015.
} 
Tabel 4: Pembiayaan BUS dan UUS

Berdasarkan Sektor Ekonomi

Per 30 April 2015 (dalam miliar rupiah)

\begin{tabular}{|c|c|c|}
\hline Sektor Ekonomi & Jumlah & Persentase \\
\hline $\begin{array}{l}\text { Pertanian, Kehutanan, dan } \\
\text { sarana pertanian }\end{array}$ & 6554 & $3 \%$ \\
\hline Pertambangan & 5165 & $3 \%$ \\
\hline Perindustrian & 14475 & $7 \%$ \\
\hline Listrik, Gas dan Air & 5655 & $3 \%$ \\
\hline Konstruksi & 11465 & $6 \%$ \\
\hline $\begin{array}{l}\text { Perdagangan, Restoran, } \\
\text { hotel }\end{array}$ & 26476 & $13 \%$ \\
\hline $\begin{array}{l}\text { Pengangkutan, Pergudangan } \\
\text { dan Komunikasi }\end{array}$ & 14105 & $7 \%$ \\
\hline Jasa Dunia Usaha & 69209 & $34 \%$ \\
\hline Jasa Sosial/ Masyarakat & 11176 & $6 \%$ \\
\hline Lain-Lain & 37247 & $18 \%$ \\
\hline & 201527 & $100 \%$ \\
\hline
\end{tabular}

Sumber: Statistik OJK RI ${ }^{3}$
Tabel 5: Pembiayaan BPRS

Berdasarkan Sektor Ekonomi

Per 30 April 2015 (dalam juta rupiah)

\begin{tabular}{|c|c|c|}
\hline Sektor Ekonomi & Jumlah & Persentase \\
\hline $\begin{array}{l}\text { Pertanian, Kehutanan, dan } \\
\text { sarana pertanian }\end{array}$ & 264579 & $5 \%$ \\
\hline Pertambangan & 7968 & $0.15 \%$ \\
\hline Perindustrian & 59852 & $1 \%$ \\
\hline Listrik, Gas dan Air & 12413 & $0.23 \%$ \\
\hline Konstruksi & 279906 & $5 \%$ \\
\hline $\begin{array}{l}\text { Perdagangan, Restoran, } \\
\text { hotel }\end{array}$ & 1989033 & $37 \%$ \\
\hline $\begin{array}{l}\text { Pengangkutan, } \\
\text { Pergudangan } \\
\text { dan Komunikasi }\end{array}$ & 91754 & $2 \%$ \\
\hline Jasa Dunia Usaha & 288917 & $5 \%$ \\
\hline Jasa Sosial/ Masyarakat & 439045 & $8 \%$ \\
\hline Lain-Lain & 1892633 & $36 \%$ \\
\hline & 5326100 & $100 \%$ \\
\hline
\end{tabular}

\section{KAJIAN PUSTAKA}

\subsection{Penelitian Terdahulu}

Begitu banyak penelitian yang telah dilakukan untuk meningkatkan kualitas pemikiran dan penerapan sistem ekonomi syari'ah. Akan tetapi dari pemikiran-pemikiran tersebut masih banyak yang menggunakan pendekatan mean stream, sehingga pemikiran yang dibangun hanyalah bagaimana ekonomi syari'ah bisa memiliki badan yang bisa memenangkan persaingan dengan sistem ekonomi yang lain. Disamping itu lahirnya lembaga keuangan syari'ah yang juga menjadi indikator perkembangan sebuah sistem perekonomian lebih hanya dipandang sebagai sebuah lembaga yang bisa mengatasi masalah keuangan semata. Sehingga kemunculan lembaga keuangan syari'ah bukan hanya semata-mata untuk memenuhi persaingan ideologi, akan tetapi kemampuan bersaing dalam dunia bisnis tanpa menghilangkan esensi ideologi menjadi hal yang penting dan menarik untuk diperhatikan.

Padahal sebenarnya munculnya lembaga keuangan tersebut harus juga disertai dengan spirit yang dibawa oleh ideologinya. Ekonomi yang islami menjadi penting untuk dimiliki oleh masyarakat muslim, apalagi mayoritas penduduknya adalah islam. Akan tetapi ada beberapa hal yang mempengaruhi manusia dalam pola kehidupan ekonominya sebagaimana yang diungkapkan Chapra (2000:24) berikut "there are a number of institutions in human society that influence individual and society outcomes. The market is only one of them. Some other are family, society and the state."

Sehingga dengan hal tersebut bisa diperhatikan tentang adanya pengaruh pasar, masyarakat dan negara terhadap kehidupan perekonomian suatu masyarakat. Maka ketika masyarakat ingin mengembangkan sebuah sistem perekonomian yang berbasis islam tentunya semangat ideologi dan budaya yang membentuk sistem perekonomian tersebut haruslah sesuai dengan konsep ideologis yang dibawa. Sehingga aplikasi sistem perekonomian yang dibangun tidak kehilangan spirit dan karakteristiknya yang tidak hanya sebagai pemenuhan ekspektasi pasar sesaat.

\footnotetext{
${ }^{3}$ http://www.ojk.go.id/data-statistik-perbankan-syariah /diakses tanggal 5 Oktober 2015.
} 
Ekonomi syari'ah membutuhkan fondasi pengembangan yang kokoh untuk terus berlanjut sebagai sebuah sistem ekonomi yang seharusnya menjadi pilihan bukan lagi alternatif. Akan tetapi hal ini membutuhkan peran serta masyarakat untuk membiasakan diri bertransaksi secara syari'ah dengan segenap kesadaran konsekuensi plus dan minusnya serta dukungan regulasi pemerintah yang mendukung bukan hanya pertumbuhan secara statistik lembaga keuangan syari'ah akan tetapi juga konsistensi penerapan sistem perekonomian syari'ah tersebut. Sehingga aplikasi sistem ekonomi tersebut bisa menjadikannya sebuah karakteristik yang menguatkan alasan untuk memilih untuk menggunakan sistem tersebut.

Disamping itu ketersediaan tenaga yang tidak hanya memahami konsep syari'ah dan kurang cepat beradaptasi dengan konsep ekonomi modern akan melahirkan sebuah kesenjangan harapan baru akan pencapaian sistem perekonomian islam. Karena aplikasi bisnis islami hanya akan menjadi sebuah pengikut sistem ekonomi lama dengan kemasan yang baru tanpa adanya karakteristik yang bisa membedakannya. Disamping itu adanya sumber daya manusia yang hanya mampu menangkap peluang berkembangnya pasar ekonomi islam tanpa didasari oleh semangat berekonomi yang berketuhanan akan melahirkan sebuah pengamalan yang berorientasi pasar tanpa adanya semangat untuk konsisten dalam pengamalannya.

Sakai (2010) dalam penelitian yang telah dilakukan atas peran BMT di Jawa Tengah dalam kegiatan perekonomian para wanita, dimana pada penelitian tersebut disampaikan bahwa memang skema penghimpunan dan penyaluran dana yang dilakukan oleh BMT tidak didesain khusus untuk kaum wanita. Akan tetapi dengan adanya lembaga keuangan tersebut, maka kegiatan perekonomian masyarakat pada area beroperasinya BMT tersebut juga akan terbantu. Karena BMT melandaskan operasionalnya kepada keadilan sosial dan kerjasama di dalam kegiatan perekonomian. Disamping itu BMT secara khusus juga bisa menanggulangi kebutuhan dana masyarakat khususnya kaum wanita yang tidak dilayani oleh dunia perbankan formal.

Penelitian ini diarahkan kepada bagaimana berdasarkan data perkembangan aktivitas perekonomian syari'ah, lembaga keuangan yang bisa menyelamatkan tujuan mulia penerapan ekonomi syari'ah tersebut dapat tercapai. Sehingga bidang kajian bagaimana pengembangan lembaga keuangan syari'ah sebagai ujung tombak pengaplikasian sistem ekonomi syari'ah tersebut perlu untuk terus dilakukan dengan segala bentuk kelebihan dan kekurangannya. Koperasi dan BMT merupakan lembaga keuangan yang sangat potensial untuk menjawab tantangan tersebut, karena landasan filosofis gotong royong yang melandasinya sangat sesuai dengan ajaran agama islam pada khususnya dan kebudayaan serta karakteristik bangsa Indonesia pada umumnya.

\subsection{Kajian Pustaka}

\subsubsection{Badan Usaha}

Asyhadie (2009:35) menyebutkan bahwa Perusahaan adalah setiap badan usaha yang menjalankan kegiatan dalam bidang perekonomian secara terus menerus, bersifat tetap dan terang-terangan dengan tujuan untuk memperoleh laba yang dibuktikan dengan pembukuan. Sehingga yang namanya badan usaha adalah tidak hanya sah secara hukum ataupun berbadan hukum, akan tetapi juga menjalankan kegiatannya secara terus menerus atau secara berkesinambungan.

Maka atas dasar pengertian diatas, perusahaan diperlukan dalam kegiatan perekonomian apapun jenisnya. Akan tetapi suatu sistem perusahaan pastinya akan melakukan tindakan operasionalnya sesuai dengan ideologisnya dan karakteristik dari badan usaha tersebut. Adapun jenis-jenis badan usaha adalah persekutuan perdata, persekutuan firma, persekutuan komanditer, perseroan terbatas, dan badan usaha milik negara. Adapun penjelasan masing-masing adalah sebagai berikut:

1. Persekutuan Perdata: suatu persekutuan yang dibentuk atas suatu perjanjian, dimana dua orang atau lebih mengikatkan diri untuk memasukkan sesuatu (inbreng) ke dalam persekutuan dengan maksud untuk membagi keuntungan. (RT. Sutandya R. Hadikusuma dan Sumantoro, 1991:13 dalam Asyhadie (2009:35)) 
2. Firma: suatu jenis persekutuan perdata yang khusus didirikan untuk menjalankan perusahaan dengan nama bersama.

3. Persekutuan komanditer: suatu firma yang mempunyai satu atau beberapa orang sekutu komanditer.

4. Perseroan terbatas: suatu bentuk usaha yang berbadan hukum yang tertuju pada tanggung jawab pemegang saham yang hanya terbatas kepada nilai nominal dari semua saham yang dimilikinya. Menurut UU No. 40 Tahun 2007 tentang perseroan terbatas adalah badan hukum yang merupakan persekutuan modal, didirikan berdasarkan perjanjian, melakukan kegiatan usaha dengan modal dasar yang seluruhnya terbagi dalam saham dan memenuhi persyaratan yang ditetapkan dalam undang-undang ini serta peraturan pelaksananya (Silondae dan Andi (2013:97).

5. Badan Usaha Milik Negara: badan usaha yang seluruh atau sebagian besar modalnya dimiliki oleh negara melalui penyertaan secara langsung yang berasal dari kekayaan negara yang dipisahkan.

6. Koperasi: badan hukum yang didirikan oleh orang perseorangan atau badan hukum koperasi, dengan pemisahan kekayaan para anggotanya sebagai modal untuk menjalankan usaha, yang memenuhi aspirasi dan kebutuhan bersama di bidang ekonomi, sosial, dan budaya sesuai dengan nilai dan prinsip koperasi. (UU No. 25 tahun 1992 tentang perkoperasian).

\subsubsection{Ekonomi Syari’ah}

Banyak pihak yang telah menginterpretasikan ekonomi syari'ah, mulai dari yang bersifat normatif sampai dengan positif, dimana banyak yang hanya memahami sebagai sistem ekonomi yang tidak ribawi. Di lain pihak ada juga yang mengartikannya sebagai sebuah sistem ekonomi yang berdasarkan nilai-nilai keislaman. Namun secara positif seharusnya sistem ekonomi islam juga harus ditunjang oleh ilmu-ilmu terkait yang mendukung suatu perekonomian dan tidak hanya dalam sebuah kemasan syari'ah yang berhaluan sistem pasar.

Menurut Mozer Kahf (1978) menyatakan bahwa ekonomi islam adalah bagian dari ilmu ekonomi yang bersifat interdesipliner. Sehingga sebagai sebuah sistem akan membutuhkan banyak sekali cabangcabang ilmu yang lain yang harus digunakan sebagai penunjang dari pelaksanaan sistem tersebut. Di sisi lain kemunculan semangat untuk memunculkan dan menjalankan ekonomi islam sebagai sebuah pilihan dan tidak lagi menjadi alternatif seharusnya diikuti dengan perkembangan ilmu-ilmu pendukung dalam bidang ekonomi, yaitu bisnis, akuntansi dan manajemen (Al Arif dan Euis, 2010:7).

Sehingga perkembangan ekonomi islam akan menjadi suatu penerapan sistem yang komprehensif, bukan lagi menjadi sistem ekonomi penghimpunan dan penyaluran dana yang islami. Karena dalam suatu perekonomian tidak hanya berpusar kepada kegiatan menghimpun dan menyalurkan dana, akan tetapi banyak hal lain, yaitu produksi dan konsumsi serta distribusinya, pencatatan dan pelaporannya, pengaturan dan optimalisasinya.

Maka ketika ada pembahasan sistem ekonomi islam tidak hanya membahas tentang bagaimana akad dalam penghimpunan dan penyaluran dana yang halal dengan mengenyampingkan kehidupan ekonomi yang komprehensif seperti yang dicontohkan oleh Rasulullah, SAW. Sehingga ekonomi syari'ah tidak hanya menjadi peluang bisnis semata atau yang lebih dikenal dalam setiap propaganda pengembangan ekonomi islam yaitu menjadi sistem ekonomi alternatif. Akan tetapi nantinya akan menjadi sebuah sistem ekonomi pilihan, jika sistem ekonomi syari'ah dikembangkan dan diaplikasikan berdasarkan model tata kelola ekonomi yang dilakukan oleh Rasulullah, dimana tidak hanya aspek keuntungan yang diperhatikan akan tetapi, sosial ekonomi, pembangunan yang berkelanjutan juga menjadi perhatian dalam hal ekonomi islam.

Ajaran islam mungkin akan mengarahkan kepada praktek akuntansi dan perbankan islam yang akan membentuk keadilan sosial, bekerja dengan komunitas lokal, menjamin kesempatan bisnis bagi yang memiliki cash flow rendah, pengambilan keputusan berdasarkan kriteria keuangan, lingkungan, akuntabilitas dan transparansi yang seharusnya semua terpusat kepada praktek akuntansi dan perbankan islam (Kamla, 2009:924). Sehingga lahirnya sistem ekonomi islam harusnya menjadi pilihan untuk ekonomi yang berkesinambungan dan terwujudkannya keadilan sosial seperti yang menjadi amanat konstitusi Negara Kesatuan Republik Indonesia. 


\subsubsection{Lembaga Keuangan Syari’ah}

Untuk mewujudkan tumbuh dan berkembangnya sistem ekonomi syari'ah yang pada masa kontemporer ini dimotori oleh lembaga keuangan, maka keberadaan lembaga keuangan haruslah terus dijaga. Adapun lembaga keuangan tersebut telah banyak sekali bermunculan baik sebagai lembaga intermediasi keuangan, finance, asuransi, pasar modal syari'ah dan beberapa lembaga nirlaba yang juga telah menjadi perhatian masyarakat sebagai bagian tak terpisahkan dari sistem perekonomian berbasis nilai-nilai islam. Sehingga perlu diperhatikan dengan baik, dari sekian banyak lembaga keuangan tersebut yang manakah yang akan mendukung terwujudnya nilai-nilai luhur sistem perekonomian syari'ah.

1. Lembaga keuangan syari'ah berbasis intermediasi keuangan

Lembaga keuangan syari'ah pada kelompok ini melakukan kegiatan dengan cara menghimpun dana dari masyarakat dan menyalurkannya kembali kepada masyarakat. Jadi menghimpun dana dari masyarakat yang memiliki surplus dana dan menyalurkannya kepada masyarakat yang defisit dana. Hal ini dilakukan oleh lembaga keuangan konvensional maupun syari'ah, baik dalam bentuk koperasi, BMT, Bank Perkreditan Rakyat, Bank Pembiayaan Rakyat Syari'ah, Bank umum dan juga Bank Umum Syari'ah.

Keberadaan lembaga keuangan konvensional sebagai lembaga intermediasi keuangan sebenarnya secara aplikatif telah didahului oleh tata kelola ekonomi dunia islam. Karena dalam islam dikenal dengan adanya zakat, infaq dan shadaqah yang menjadi kewajiban ummat islam yang memiliki kelebihan dana untuk mengalokasikan sejumlah dananya kepada masyarakat yang membutuhkan baik secara suka rela ataupun yang bersifat memaksa. Adapun tata kelola tersebut dilakukan oleh baitul maal pada masa Rasulullah dan keemasan peradaban islam. Sehingga semangat untuk kembali ke pemahaman ajaran yang berlandaskan nilai-nilai agama tersebut yang kemudian menggerakkan masyarakat untuk mendirikan lembaga keuangan yang berbasis intermediasi keuangan yang berbasis syari'ah.

Untuk mengakomodasi kepentingan pihak-pihak yang memiliki bakat entrepreneurship skill dengan kendala modal, lembaga ekonomi syari'ah memiliki stok tertentu, terutama modal yang dihimpun dari dana zakat, infaq dan shadaqah. Kemudian dikemas dalam bentuk produk al qard al hasan, pinjaman kebajikan yang bisa disalurkan kepada mareka (Muhammad, 2005:69). Sehingga dengan skema ini lembaga ekonomi syari'ah memberikan peluang kepada masyarakat untuk menggali kreatifitas dan kerja yang tinggi dengan memanfaatkan modal yang ada dalam membangun roda ekonominya. Adanya lembaga keuangan non formal seperti BMT tersebut akan menjadikan kelompok ekonomi lemah yang selama ini tidak tersentuh oleh lembaga keuangan formal memiliki kesempatan yang sama untuk mengakses modal pembiayaan dari lembaga ekonomi syari'ah. Yang kemudian perkembangan sektor riil bisa lebih cepat terwujud dalam sistem berbasis kerja sama.

2. Lembaga keuangan syari'ah berbasis pembiayaan

Lembaga keuangan syari'ah yang berbasis pembiayaan (finance) ini tidak menghimpun dana dari masyarakat dalam kegiatan operasionalnya. Akan tetapi dalam kegiatan usahanya akan tetap dilakukan dalam bentuk menyalurkan dana langsung kepada masyarakat, baik dalam bentuk pembiayaan konsumtif ataupun produktif. Adapun lembaga keuangan syari'ah yang berbasis pembiayaan ini akan lebih mengarahkan kegiatan usaha penyaluran dananya kepada kebutuhan pembiayaan yang bersifat konsumtif. Karena skema pembiayaan yang ditawarkan memang lebih kepada untuk memfasilitasi kebutuhan masyarakat terhadap hal-hal yang bersifat konsumtif (perumahan, kendaraan, kebutuhan keuangan jangka pendek) yang sesuai dengan ketentuan syari'ah.

Akad-akad yang bersifat finance tersebut banyak disediakan oleh lembaga-lembaga pegadaian yang menyediakan layanan rahn dan ijarah. Sehingga kebutuhan jangka pendek tetap terpenuhi dengan cepat tanpa harus menghilangkan keterpenuhan akan unsur syarat dan ketentuan transaksi dalam syari'ah. Selain itu lembaga yang juga banyak bermunculan adalah lembaga leasing yang berbasis syari'ah untuk memenuhi kebutuhan masyarakat untuk membeli barang-barang yang dibutuhkan dengan pembayaran angsuran (Salman, 2012:7).

Disamping itu kadang kala muncul juga kebutuhan masyarakat untuk memenuhi kebutuhan dananya dengan melakukan diskonto atas piutang yang dimiliki. Maka untuk tetap memberikan pelayanan 
kepada masyarakat dengan tidak melanggar syari'ah, muncullah akad jasa hiwalah yang juga banyak diberikan oleh bank yang berbasis lembaga intermediasai keuangan ataupun lembaga lain yang sah untuk memberikan layanan tersebut. Akan tetapi berdasarkan prinsip jasa yang diberikan, hal ini bisa dilakukan oleh lembaga khusus yang menangani anjak piutang

3. Lembaga keuangan syari'ah berbasis asuransi

Asuransi muncul sebagai bentuk tanggung jawab sosial untuk saling tolong menolong dalam kehidupan bermasyarakat. Sehingga dalam kehidupan bermasyarakat ada semangat bersama untuk saling menjamin antar masyarakat. Adapun perbedaan asuransi konvensional dengan asuransi takaful adalah terletak pada proses pengelolaan premi yang dibayarkan oleh anggota asuransi.

Jika pada asuransi konvensional, premi yang dibayarkan oleh nasabahnya akan diinvestasikan dan dikelola untuk mendapatkan keuntungan sebagai kompensasi atas jaminan atas kerugian yang akan diberikan oleh perusahaan asuransi. Sehingga dalam perusahaan asuransi konvensional, dana yang terkumpul akan bebas diinvestasikan pada segala bentuk kegiatan usaha tanpa memperhatikan unsur syari'ah dan keuntungan yang dijanjikan bersifat tetap. Sedangkan dalam asuransi syari'ah yang biasa dikenal dengan asuransi takaful, maka ada sebagian dana premi yang dicadangkan untuk menjadi dana tolong menolong ketika ada anggota asuransi tersebut mengalami kerugian. Sementara dana yang lain akan diinvestasikan ke dalam jenis usaha yang diperbolehkan dalam ketentuan syari'ah. Disamping itu balas jasa yang akan diberikan juga tidak dipersyaratkan dengan tegas di awal.

Adapun industri asuransi syari'ah pada akhir-akhir ini telah berkembang dengan cepat dengan naiknya kesadaran masyarakat dalam mengasuransikan setiap potensi dirinya dari kerugian yang mungkin timbul. Adapun perkembangan ini didukung juga dengan peningkatan kesadaran masyarakat untuk menggunakan transaksi-transaksi yang berbasis syari'ah. Maka pada beberapa asuransi yang awalnya juga beroperasi dengan konsep asuransi konvensional telah juga menyediakan produk yang berbasis syari'ah.

4. Lembaga keuangan syari'ah berbasis pasar modal syari'ah

Pasar modal syari'ah juga telah menghiasi perkembangan dan dinamika perekonomian syari'ah, dimana pasar modal sebagai salah satu wahana investasi harus juga mengikuti perkembangan dinamika keinginan masyarakat untuk menginvestasikan dananya dengan tidak meninggalkan nilai-nilai luhur ajaran agamanya. Sehingga kemunculan entitas ekonomi yang mampu menjadi ruang investasi saham dan surat berharga lain yang sesuai dengan ajaran islam harus segera dimunculkan. Adapun kemunculan lembaga pasar modal ini akan menjadi jawaban atas kebutuhan masyarakat tersebut, dan di Indonesia telah dikenal beberapa indeks yang berbasis syariah seperti Jakarta Islamic Index (JII) dan Indeks Saham Syari'ah Indonesia (ISSI).

5. Lembaga keuangan berbasis entitas nirlaba

Lembaga keuangan berbasis entitas nirlaba ini adalah lembaga keuangan yang menghimpun dan menyalurkan dananya dengan prinsip syari'ah dan tidak dibentuk untuk menghasilkan laba. Akan tetapi keberadaan lembaga keuangan tersebut hanya untuk mengakomodir kegiatan-kegiatan sosial. Disebut lembaga keuangan karena berhubungan dengan pengelolaan keuangan yang dilakukan oleh lembaga tersebut, meskipun untuk kegiatan sosial.

Dalam hal ini lembaga keuangan yang menggunkan prinsip tata kelola syari'ah diantaranya adalah Badan Amil Zakat, Masjid, Pesantren (tempat pendidikan islam) dan lembaga-lembaga lain yang melakukan kegiatan nirlaba yang berbasiskan ajaran islam. Dalam hal ini Badan Amil Zakat Nasional (BAZNAS) saja telah mengumpulkan dan menyalurkan dana yang sedemikian besar dan berdasarkan data perbandingan tahunan yang didapatkan dari laporan BAZNAS pengumpulan dana Zakat,Infaq dan Shadaqah selama tahun 2012 dan 2013 adalah sebagai berikut: 
Jurnal IImiah Bidang Akuntansi dan Manajemen (JEMA) Vol. 14 No. 1 (2017)

http://riset.unisma.ac.id/index.php/jema

Tabel 6 Laporan Penerimaan dan Penyaluran Dana Zakat Badan Amil Zakat Nasional

\begin{tabular}{|l|c|c|}
\hline & $\mathbf{2 0 1 2}$ & $\mathbf{2 0 1 3}$ \\
\hline Penerimaan sampai akhir tahun & $50,220,719,886.92$ & $59,019,259,845.87$ \\
\hline Penyaluran dana sampai akhir tahun & $38,513,551,378.00$ & $44,363,070,093.00$ \\
\hline
\end{tabular}

Sumber, BAZNAS ${ }^{4}$

Bisa diperhatikan bahwa meskipun dana yang bergulir untuk dana sosial hanya pada satu lembaga yaitu BAZNAS sudah sedemikian besar dalam satu tahun. Jika seluruh lembaga keuangan nirlaba yang seharusnya berbasis syari'ah mendokumentasikan kegiatannya dengan baik dan mempublikasikan pertanggungjawaban keuangannya sesuai dengan standar. Maka bisa dipastikan sedemikian besar jumlah perputaran uang yang berada dalam lingkaran lembaga keuangan ini dan seharusnya bisa meningkatkan taraf hidup masyarakat dengan variabilitas akad yang dimiliki oleh lembaga keuangan syari'ah. Lembaga keuangan jenis inipun seharusnya sudah menjadi perhatian untuk dikembangkan dan menjadikannya suatu karakteristik yang tidak hanya berfungsi sosial, akan tetapi juga berfungsi ekonomis.

\section{METODE PENELITIAN}

Penelitian ini dapat digolongkan ke dalam penelitian deskriptif dimana peneliti ingin menganalisa data yang yang telah dikumpulkannya melaui proses riset kualitatif. Peneliti menggunakan studi literartur dan observasi dalam usahanya untuk mendeskripsikan sebuah fenomena.

\section{PEMBAHASAN HASIL PENELITIAN}

Konsep pembangunan berkelanjutan adalah konsep ekonomi yang berketuhanan, dimana dari sifatnya yang kekal menyiratkan adanya sistem manajerial yang baik yang sepatutnya menjadi pembelajaran bagi manusia. Bahkan secara tegas dalam QS. Al-Maidah ayat 2 yang dengan jelas mengajarkan kerja sama dalam hal kebaikan. Seperti di Indonesia, berdasarkan nilai-nilai luhur yang diamanatkan dalam konstitusi Negara Kesatuan Republik Indonesia yaitu UUD 1945 pasal 33 ayat 1 yang menyatakan bahwa "Perekonomian disusun sebagai usaha bersama berdasar atas azas kekeluargaan". Sehingga berdasarkan ajaran agama mayoritas penduduk Indonesia tidak ada keraguan untuk mengembangkan pola perekonomian yang saling bekerja sama untuk menuju kualitas kehidupan yang lebih baik dan pembangunan ekonomi yang berkesinambungan.

Di lain hal, koperasi yang melandaskan operasionalnya pada nilai-nilai seperti yang dicantumkan dalam pasal 5 ayat 1 UU Nomor 25 tahun 1992 tentang perkoperasian:
a. Keanggotaan bersifat suka rela dan terbuka
b. Pengelolaan dilaksanakan secara demokratis
c. Pembagian sisa hasil usaha dilakukan secara adil sebanding dengan besarnya jasa usaha masing- masing anggota
d. Pemberian balas jasa yang terbatas terhadap modal
e. Kemandirian

Dari nilai-nilai yang diamanatkan tersebut tergambar bahwa koperasi adalah suatu perwujudan badan usaha yang keanggotaannya berdasarkan atas cita-cita luhur untuk menguatkan posisi ekonomi diri sendiri yang berdasarkan azas kekeluargaan. Sehingga tidak akan ada eksploitasi sepihak karena semua anggota memiliki hak yang sama dalam pengambilan keputusan dan tidak bertumpu pada akumulasi modal. Disamping itu juga karena adanya semangat kebersamaan yang bertanggung jawab, maka seharusnya tidak akan ada asimetri informasi yang akan menjadikan pemilik informasi lebih berpengaruh dibandingkan yang lain.

\footnotetext{
${ }^{4}$ http://pusat.baznas.go.id/wp-content/uploads/downloads/2015/06/laporan-desember-2014.pdf (diakses tanggal 3 November 2015)
} 
Adapun menanggapi masalah rendahnya penyaluran dana yang berbasis bagi hasil yang menjadi karakteristik lembaga keuangan syari'ah yang kemunculannya sebagai jawaban atas ketidakberhasilan sistem perekonomian dengan sistem bunga. Karena penyaluran dana dengan menggunakan instrumen bagi hasil bagi bank umum syari'ah yang hanya 33\% dan lebih menyedihkan lagi bank pembiayaan rakyat syari'ah menyalurkan dananya dalam konsep bagi hasil hanya sebesar 79\%. Hal ini sesuatu hal yang menyedihkan, dimana masyarakat beranggapan bahwa tidak ada perbedaan antara lembaga keuangan syari'ah dengan lembaga keuangan konvensional.

Hal tersebut bukanlah tanpa alasan, karena penyaluran dana dalam instrumen pembayaran tetap berbasis murabahah merupakan pilihan dari sebagain besar lembaga keuangan syari'ah. Instrumen pembayaran tetap yang lain biasanya yang ditawarkan oleh lembaga keuangan mikro adalah penyaluran dana berbasis fee. Sehingga dari sudut pandang bisnis masyarakat tidak ada kelebihan yang dimiliki oleh lembaga keuangan syari'ah dalam hal biaya modal yang harus dibayar oleh nasabah pembiayaan lembaga keuangan syari'ah. Kecuali yang menarik adalah terpenuhinya kebutuhan dana jangka pendek masyarakat oleh lembaga keuangan mikro syari'ah, karena memang banyak sekali menawarkan jasa pegadaian yang secara keamanan penyaluran dana lebih tinggi dibandingkan dengan prinsip bagi hasil.

Adapun fakta yang terkait dengan fakta dan masalah yang timbul dalam penyaluran dana yang bertumpu kepada basis margin adalah sebagai berikut:

\section{a. Resiko asimetri informasi antara mudharib dengan shahibul maal}

Asimetri informasi menjadikan suatu ancaman tersendiri bagi para pelaku bisnis untuk memutuskan kerja sama bisnis secara tepat. Karena informasi yang dikuasai secara sepihak akan cenderung merugikan pihak yang kurang memiliki informasi. Sehingga kerja sama dengan asimetri informasi akan cenderung terjadinya eksploitasi sepihak, dimana pihak yang menguasai informasi akan bisa melakukan keputusankeputusan strategik dan tekhnis yang lebih menguntungkan dirinya.

Dalam konsep penyaluran dana oleh lembaga keuangan syari'ah, didapatkan fakta bahwa dalam skema bagi hasil sangat rendah. Sehingga karakteristik sistem ekonomi syari'ah tidak bisa ditunjukkan, karena konsep kerja sama dalam membangun perekonomian tidak dilakukan. Akan tetapi dalam tata kelolanya menekankan kepada keamanan penyaluran dana dan menghindari adanya non performing loan (NPL).

Lalu atas dasar itulah kemudian bisa disimpulkan bahwa berkembangnya sistem perekenomian syari'ah tidak hanya menyangkut berkembangnya jumlah nasabah, jumlah kantor, karyawan ataupun laba yang dihasilkan. Akan tetapi perkembangan sistem perekonomian syari'ah juga bisa ditandai dengan berkembangnya kualitas pelaksanaan dengan konsistensi yang baik atas akad transaksi syari'ah yang juga tidak menghilangkan esensi nilai atas penerapan akad tersebut. Untuk menuju terbentuknya sistem perekenomian syari'ah yang baik, maka masalah asimetir informasi harus diselesaikan dengan meningkatkan kesadaran akuntabilitas bagi mitra-mitra perbankan dengan penuh kesadaran.

Bahkan tidak ada kesenjangan harapan informasi antara nasabah penabung dengan bank, hal ini mungkin disebabkan oleh rendahnya nilai tabungan yang ditempatkan. Sehingga untuk memperoleh informasi yang lebih banyak bukanlah hal yang penting bagi nasabah. Adapun nasabah deposito mudharabah yang seharusnya mendapatkan bagi hasil dan menuntut adanya informasi yang lebih besar untuk memperhitungkan hak bagi hasilnya juga tidak membutuhkan informasi yang lebih besar, karena nasabah tersebut menabung lebih karena keharusan membayar cicilan pembiayaan yang diperoleh dari bank syari'ah (yaya, aji dan ahim, 2014:98).

Disamping itu kebanyakan tabungan yang membentuk modal kerja nasabah adalah tabungan wadi'ah yang berbasis bonus. Sehingga tidak ada kewajiban lembaga keuangan syari'ah untuk memberikan balas jasa kepada nasabahnya dan nasabah juga tidak mengharapkan kembalian atas dana yang dititipkannya. Atas dasar inilah kemudian lembaga keuangan hanya cukup saja mengamankan dana yang diterimanya dan tidak ada beban untuk harus memberikan balas jasa tertentu.

Jika sudah tidak ada kesenjangan harapan antara nasabah dengan lembaga keuangan syari'ah dalam hal laporan dan media pelaporan keuangan terkait dana simpanannya. Maka kemudian, apakah dalam penyaluran dana dengan akad kerja sama tidak bisa dilakukan dengan skema bagi hasil yang 
membutuhkan informasi yang simetri antara mudharib dengan shahibul maal, dimana lembaga keuangan syari'ah akan berfungsi sebagai manajer investasi yang akan mengarahkan investasi nasabah ke investasi yang aman dan tidak meninggalkan prinsip-prinsip nilai luhur ajaran ekonomi islam.

Asimetri informasi inilah yang cenderung menjadikan dunia lembaga keuangan syari'ah cenderung untuk lebih hati-hati dalam menyalurkan dananya. Karena informasi yang diterima dan disajikan oleh pemohon pembiayaan terkait keuangan dan proyeksi yang diberikan tidak sesuai dengan standar dan bagi lembaga keuangan mikro syari'ah hanya melihat riil jaminan yang diberikan tanpa bisa menginterpretasikan laporan posisi keuangan dan kinerja dengan baik. Sehingga pembiayaan yang dimunculkan hanyalah pembiayaan-pembiayaan dengan resiko rendah dan tidak melanggar aturan syari'ah. Selain itu dalam penetapan margin khususnya, nasabah pembiayaan hanyalah mendapatkan konsep yang ditawarkan dengan skema pembayaran yang ditawarkan oleh pihak lembaga keuangan syari'ah.

Hal ini akan menjadikan juga asimetri informasi atas penetapan margin kepada nasabah, dimana nasabah hanya menjadi objek untuk mendapatkan keuntungan dari lembaga keuangan tersebut. Maka munculnya pernyataan dari masyarakat tentang tidak ada perbedaan yang signifikan antara lembaga keuangan konvensional dengan syari'ah adalah karena skema pembayaran angsuran dan keuntungan yang didapatkan oleh lembaga keuangan bersifat tetap. Disamping itu penentuan keuntungan ataupun margin juga ditentukan di awal kontrak dengan nasabah sudah harus mengikuti ketentuan lembaga keuangan. Meskipun hal itu dibolehkan, akan tetapi terciptanya asimetri informasi akan semakin mengemuka.

\section{b. Resiko moral hazard mudharib}

Di Indonesia memang sudah sedemikian banyak kasus yang menyalahgunakan wewenang yang berdimensi terhadap kebocoran keuangan. Hal ini terjadi karena dekadensi moral yang terus terjadi, sehingga banyak sekali terjadi tindakan manipulasi keuangan yang merugikan pihak lain. Maka dalam kaitannya dengan investasi yang harus diberikan oleh lembaga keuangan syari'ah dalam bentuk pembiayaan bagi hasil akan sangat sulit dilakukan, karena masyarakat yang memohon pembiayaan sangat sulit dibedakan yang akan melakukan moral hazard dengan yang tidak akan melakukannya.

Hal ini juga mengindikasikan telah menurunnya nilai-nilai kemanusiaan. Sehingga tidak jarang harga barang menjadi lebih mahal dibandingkan nilai-nilai kemanusian. Manusia yang seutuhnya seharusnya meskipun hanya berupa fisik akan lebih mahal dibandingkan hewan dan harta tetap berwujud lainnya, apalagi manusia yang seutuhnya dengan karakter dan moral yaang dijunjung tinggi. Selain itu moral hazard juga bisa ditanggulangi dengan jalan pengawasan yang lebih efektif dan efisien.

\section{c. Biaya kontrol}

Yang menjadi masalah mendasar juga adalah kontrol yang harus dilakukan jika bentuk penyaluran dananya dalam skema bagi hasil. Karena dengan skema tersebut diperlukan kemitraan yang berkesinambungan antara lembaga keuangan syari'ah dengan nasabah. sehingga dengan adanya kerja sama akan menuntut juga biaya kontrol yang lebih besar dibandingkan dengan skema pembiayaan dengan pembayaran angsuran tetap dan pendapatan atas penyaluran dana tersebut juga yang bersifat tetap. Akan tetapi dengan konsep seperti itu nilai luhur ekonomi islam yang berbasis kerja sama (taawun) akan semakin hilang dan menjelma menjadi lembaga keuangan yang berbasis intermediasi keuangan yang dihalalkan dan menghilangkan fungsi lembaga keuangan yang akan menjadi lembaga intermediasi potensi.

\section{d. Tingkat keamanan penyaluran dana}

Tingkat keamanan penyaluran dana juga menjadi faktor yang sangat penting dalam konsep penyaluran dana. Sehingga harus disalurkan dengan baik kepada pihak-pihak yang bisa dipercaya, sehingga banyak sekali lembaga keuangan syari'ah terutama yang berbasis mikro syari'ah menyediakan jasa penyaluran dana yang berbasis keuntungan yang bersifat tetap. Karena konsep keamanan penyaluran dana itulah menjadikan lembaga keuangan syari'ah menjadi konservatif dan hanya mengejar keuntungan.

Masyarakat Indonesia masih hanya sebagian kecil yang bisa memahami perbedaan investasi dengan menabung. Sehingga sebagian melakukan tabungan dan menganggapnya sebagai kegiatan investasi, padahal tidak ada nilai tambah yang bisa dihasilkan. Hanya sebagian kecil saja yang melakukan investasi 
secara langsung dan hanya minoritas yang melakukan investasi di sektor keuangan. Sehingga budaya investasi inilah yang terkadang masih mempengaruhi masyarakat untuk menyertakan dananya dalam lembaga keuangan syari'ah dalam bentuk tabungan investasi yang jika dana tersebut digunakan, tidak akan memberatkan pihak lembaga keuangan dalam menyalurkan dananya. Karena masyarakat juga telah dengan secara sadar mengalokasikan kelebihan dananya untuk disalurkan kepada masyarakat dalam skema kerja sama dan bagi hasil dengan segala konsekuensinya.

\section{e. Pemahaman terhadap instrumen bisnis islami}

Bisnis lembaga keuangan islam merupakan bisnis yang memiliki variabilitas jenis penghimpunan dana dan penyaluran dana yang lebih banyak. Sehingga seharusnya dengan variablitas tersebut menjadi kekuatan untuk tumbuh dan berkembangnya bisnis lembaga keuangan syari'ah dengan baik. Bukan kemudian variabilitas tersebut hanya dalam penentuan kontrak, sementara karakteristik dan nilai luhurnya didekatkan satu sama lain yang kemudian membiaskan dari tujuan munculnya kontrak tersebut.

Akad yang variatif akan memberikan pilihan yang lebih memberikan keleluasaan bagi investor/ kreditor dan debitor dalam mengikatkan dirinya dalam kontrak kerja sama yang diinginkan (Baihaki, 2015:22). Dalam konteks ini seharusnya calon nasabah sendiri selain lembaga keuangan syari'ah harus juga mendorong dilakukannya akad kerja sama dan tidak ingkar atas kontrak yang telah dilakukan. Karena bisnis dalam islam tidak hanya menyangkut laba/ rugi akan tetapi ada tata nilai yang harus dilakukan sebagaimana etika bisnis Rasulullah. SAW.

Sehingga lembaga keuangan syari'ah seharusnya dituntut lebih sadar untuk mengembangkan jenisjenis produk penyaluran dananya dengan memanfaatkan kelebihan-kelebihan yang dimiliki oleh setiap akad dalam transaksi keuangan lembaga keuangan syari'ah. Jika hal tersebut dilakukan, maka tidak akan ada bias lagi antara penyaluran dana qardul hasan yang mirip dengan murabahah. Kemunculan perbankan syari'ah yang seharusnya bisa menjembatani harapan masyarakat yang memiliki surplus potensi dan minus modal kerja akan bisa diselesaikan dengan akad syari'ah yang berbasis kerja sama tidak berbasis bunga yang akan memberatkan pengusaha baru. Namun hal tersebut masih belum bisa dilakukan karena faktor pelaksana kegiatan penyaluran dana khususnya tersebut hanya berorientasi pada laba dan keamanan penyaluran dananya.

Untuk mengatasi masalah-masalah yang timbul dalam pengembangan ekonomi syari'ah baik yang bersifat tekhnis operasional, pengembangan sumber daya dan infrastruktur. Maka perlu dilakukan pendekatan kajian komprehensif yang harus dimulai dari mencari dan menentukan model entitas ataupun badan usaha secara ekonomi yang paling mendekati semangat pengembangan ekonomi syari'ah. Sehingga akan ada momentum untuk mencapai cita-cita luhur ekonomi syari'ah diperlukan tempat menyemaikan transaksi yang sesuai.

Maka untuk memecahkan masalah ketepatan badan hukum yang seharusnya digunakan untuk pengembangan ekonomi syari'ah perlu dianalisa berdasarkan beberapa faktor berikut:

\section{Faktor sejarah}

Sistem ekonomi islam berkembang dan meneladani sistem baitul maal pada zaman Rasulullah. SAW, sehingga dari nilai-nilai historis itulah maka untuk menuju pengembangan sistem ekonomi islam perlu untuk tidak melupakan sejarah. Baitul maal wat tamwil (BMT) yang berkembang sekarang ini sebenarnya tidak boleh lepas dari nilai-nilai yang telah berkembang sebelumnya, dimana sebagai lembaga pengatur kesejahteraan sosial. Akan tetapi dalam dunia kontemporer saat ini, maka lembaga tersebut tidak bisa lepas dari faktor bisnisnya.

Sedangkan BMT diterjemahkan sebagai lembaga keuangan mikro syari'ah yang berbadan hukum koperasi (Salman, 2012:10). Sehingga dengan adanya hal tersebut, maka BMT sudah sangat tepat untuk dijadikan wadah dalam pengembangan ekonomi islam tersebut. Karena BMT tidak lepas dari nilai-nilai sejarah pengembangan ekonomi islam dan mengakomodir pengembangan perekonomian yang dicita-cita oleh pendiri Negara Kesatuan Republik Indonesia.

Kemunculan ideologi perekonomian Indonesia tidak lepas dari konsep kearifan lokal masyarakat Indonesia yang mayoritas muslim yaitu gotong royong. Sehingga jika ekonomi islam dikembangkan dengan hanya mengakomodir kepentingan bisnis semata, maka perkembangan yang terjadi hanyalah 
perkembangan yang fatamorgana dengan meninggalkan substansi dan hanya terfokus kepada hal-hal yang bersifat kepentingan sesaat yaitu laba yang terbatas kepada suatu periode tertentu. Selain itu yang lebih penting adalah bagaimana peradaban itu berkembang dan tidak terpengaruh oleh kepentingan atau bahkan menjadi alat kepentingan peradaban yang lain.

\section{Faktor cita-cita ideologis badan usaha}

Setiap badan usaha memiliki cita-cita ideologisnya masing-masing, dimana perusahaan perseorangan tentunya didirikan untuk kepentingan pemiliknya. Begitupun persekutuan perdata, firma, dan persekutuan komanditer yang didirikan oleh beberapa orang atau lembaga bertujuan untuk menghasilkan laba bagi para anggotanya dengan pembagian yang disepakati. Perseroan didirikan yang berbasis modal dan tanggung jawab serta hak dan kewajibannya sesuai dengan proporsi modal penyertaannya.

Akan tetapi koperasi dibentuk dengan tujuan meningkatkan kesejahteraan anggota pada khususnya dan masyarakat pada umumnya, sekaligus sebagai bagian yang tidak terpisahkan dari tatanan perekonomian nasional yang demokratis dan berkeadilan (UU No. 25 tahun 1992 tentang perkoperasian. Adapun tujuan ekonomi islam adalah untuk mewujudkan kesejahteraan sosial (Kamla, 2009:929). Maka bisa disimpulkan bahwa untuk mewujudkan keadilan sosial diperlukan sinergitas yang tinggi yang juga berkeadilan.

Adapun berdasarkan tujuan dari cita-cita lembaga keuangan tersebut, bisa disimpulkan untuk mengembangkan sistem perekonomian syari'ah yang bertujuan untuk mewujudkan keadilan sosial yang berdasarkan konsep kerja sama diperlukan lembaga keuangan berupa koperasi atau dalam konsep bisnis lembaga keuangan syari'ahnya adalah BMT. Karena pembentukan BMT yang berbadan hukum koperasi tersebut seharusnya untuk menguatkan daya saing dan kesejahteraan anggota. Sehingga dalam tata kelolanya nantinya akan mengarah kepada pemberdayaan, karena pada intinya koperasi atau BMT dimiliki secara bersama-sama oleh anggota dan kompensasinya atau hak atas laba tergantung usaha nyata para anggota untuk memajukan koperasi tersebut. Oleh sebab itu tidak akan ada eksploitasi sepihak dari dan kepada anggota yang lain.

\section{Faktor bisnis}

Bisnis lembaga keuangan syari'ah dilihat dari perkembangannya menjadi sesuatu bisnis yang prospektif, sehingga banyak sekali kantor-kantor baru lembaga keuangan syari'ah dibuka baik dalam skala mikro, kecil, menengah ataupun korporasi. Padahal kemunculan mereka sebenarnya hanya dalam memenuhi kebutuhan akan laba dan tidak kehilangan pangsa pasarnya, terutama bagi korporasi perbankan yang induk perusahaannya masih banyak yang berupa lembaga keuangan konvensional.

Padahal jika dipahami dengan baik, bahwa bisnis islam selain berkah juga bisa menghasilkan keuntungan yang besar. Karena dengan kerja sama yang baik, akan ada banyak sekali keuntungan, yang mana tingkat keuntungan yang bisa tidak terbatas dan sektor riil akan tergerak dengan baik. Karena dengan adanya fungsi dari lembaga keuangan sebagai lembaga intermediasi potensi atau manajer investasi, maka akan menghasilkan suatu pola investasi langsung yang menggerakkan sektor riil dan tidak hanya bersifat keuangan.

Hal ini akan bisa diwujudkan dengan baik, jika dalam proses bisnis lembaga keuangan syari'ah tersebut dilakukan oleh koperasi yang biasanya bergerak di bidang usaha penyaluran produk karyawannya dan menyediakan kebutuhan anggotanya. Sehingga setiap keuntungan yang timbul dari setiap usaha para anggota akan kembali kepada para anggota tersebut. Disamping itu koperasi bisa berperan ganda sebagai suplier dan konsumen yang akan menguatkan perekonomian anggota dalam menghadapi persaingan pasar yang lebih luas. Dalam hal kebutuhan akan modal, maka skema pembiayaan yang tidak hanya berbasis margin atau menggunakan pembayaran tetap akan menjadi alternatif bagi masyarakat akar rumput yang menjadi bagian terbesar masyarakat Indonesia khususnya yang mayoritas juga beragama islam. Sehingga penyelamatan aqidah atas ekonomi merekapun harus menjadi perhatian dalam tata kelola bisnisnya. 


\section{Ketepatan untuk menjawab tantangan}

Atas lima masalah-masalah pokok tersebut diatas yang meliputi resiko asimetri informasi antara mudharib dengan shahibul maal, resiko moral hazard mudharib, biaya kontrol, tingkat keamanan penyaluran dana, pemahaman terhadap instrumen bisnis islami bisa diterapkan jika ekonomi islam dikembangkan dalam bentuk koperasi ataupun BMT. Karena dengan pengembangan sistem perekonomian dengan menggunakan lembaga keuangan BMT atau koperasi, tidak akan ada asimetri informasi. Koperasi melandaskan pengelolaan dari, oleh dan kepada anggota. Sehingga pengurus, pengawas dan pemiliknya adalah anggota.

Koperasi melandaskan operasionalnya pada kerja sama dan keunggulannya adalah memiliki tujuan untuk meningkatkan kesejahteraan anggota. Maka dengan demikian koperasi bisa menjadi badan usaha yang tepat dalam mewujudkan cita-cita luhur sistem perekonomian syari'ah yang menginginkan terwujudnya kesejahteraan sosial. Disamping itu BMT yang berbadan hukum koperasi memiliki kewajiban yang diikat oleh aqidah islam untuk juga bertanggung jawab secara sosial dalam bentuk dana zakat, infaq, shadaqah dan waqaf. Atas dana-dana yang dialokasikan ataupun dihimpun tersebut harus dilaporkan dalam laporan keuangan sesuai dengan amanat dalam standar akuntansi syari'ah 101 tentang penyajian laporan keuangan syari'ah.

Terwujudnya kesejahteraan sosial akan lebih terwujud, karena adanya pola kemitraan antara orangorang yang terlibat dalam perikatan. Baik itu dalam prinsip bagi hasil, bonus, margin ataupun sewa. Hal ini dilandasi oleh sebuah orientasi awal yang bersifat tolong menolong (Baihaki, 2015:23). Sehingga koperasi atau BMT adalah solusi terbaik untuk mewujudkan semangat bekerja sama seperti yang diajarkan oleh islam dan nilai-nilai luhur budaya bangsa yaitu gotong royong. Dengan prinsip tersebut, maka diharapkan tidak ada kesenjangan informasi dari pihak yang memerlukannya.

Moral hazard yang juga sering terjadi biasanya diakibatkan oleh kurangnya integritas penanggung jawab suatu entitas, sehingga pertanggung jawaban hanya dimaknai sebagai suatu laporan yang bersifat kuantitatif saja. Akan tetapi laporan yang seharusnya disajikan bisa memaknai sebuah aktivitas. Misalnya terbukti pada tabel 2 dan 3 tentang skema pembiayaan yang dilakukan oleh bank umum syari'ah dan BPRS lebih banyak dan bahkan diatas 50\% menggunakan akad murabahah yang berbasis margin yang jika diperhatikan sebenarnya dengan skema tersebut masalah tidak terakomodirnya pemilik potensi yang miskin modal kerja tidak terselesaikan. Pada tabel 4 dan 5 menunjukkan bahwa sektor yang banyak digeluti masyarakat belum banyak disentuh oleh skema pembiayaan BUS dan BPRS.

Sehingga hal tersebut menjadi tugas dan tanggung jawab koperasi ataupun BMT yang memiliki cakupan operasional lebih kecil dan seharusnya menyentuh kehidupan masyarakat secara langsung untuk memperhatikannya. Karena dengan model koperasi yang juga mengedepankan pembinaan kepada anggota dan melindungi kepentingan anggota maka moral hazard antara pengelola yaitu anggota yang menjadi pengurus dan anggota biasa bisa dijembatani. Karena berangkat dari tujuan dan cita-cita yang sama, sehingga sangat tidak layak untuk melakukan tindakan-tindakan yang merugikan anggota yang lain.

Untuk melakukan kerja sama yang baik antar pihak diperlukan biaya kontrol yang besar yang dimulai dari studi kelayakan sebelum terjadinya kontrak dan setelah terjadinya kontrak. Maka biasanya lembaga keuangan konvensional akan melakukan studi kelayakan dengan baik dan akan membebankan segala bentuk kejadian setelah terjadinya kontrak kepada nasabahnya. Hal ini terjadi karena keterbatasan sumber daya yang ada untuk melakukan kontrol kemitraan atas akad-akad dalam bentuk kerja sama.

Akan tetapi dengan koperasi ataupun BMT biaya kontrol itu akan menjadi lebih murah, karena ruang lingkupnya yang langsung berhadapan dengan nasabahnya dan dalam ruang lingkup satu wilayah. Selain itu koperasi ataupun BMT bisa memanfaatkan semangat para anggotanya sebagai kontrol internal atas pribadi masing-masing anggota untuk tidak menyalahgunakan kepercayaan dari anggota yang lain untuk memajukan koperasi. Yang paling penting dari itu semua adalah dalam koperasi ataupun BMT adalah setiap kenaikan pendapatan akan menjadi kenaikan pendapatan bagi seluruh anggota koperasi dan berbanding lurus juga dengan peran serta aktif para anggota koperasi untuk memajukan koperasi yang dibentuknya. 
Koperasi juga bisa menjadi wahana ataupun solusi untuk memberikan pemahaman tentang bisnis islam yang memiliki variabilitas akad yang jauh lebih komprehensif dibandingkan konvensional yang hanya berbasis bunga dan hanya dikelola dan bentuk produk yang beraneka ragam. Akan tetapi dengan koperasi maka akad-akad yang tidak familiar karena faktor resiko ataupun cakupan yang tidak terpenuhi akan menjadi solusi, karena dengan ruang lingkup yang lebih kecil maka resiko akan semakin kecil.

Sehingga adanya koperasi atau BMT diharapkan bisa meningkatkan pemakaian akad yang sesuai yang akan menuju tercapainya tujuan dari keberadaan akad syari'ah tersebut. Adanya keterterapan akad yang lebih beragam akan menunjukkan bahwa lembaga keuangan syari' ah bukanlah lembaga bisnis yang dibentuk yang hanya berubah bentuk dari akad-akad konvensional, akan tetapi memang lembaga keuangan syari'ah betul-betul memiliki ciri khas yang bisa membedakannya dengan lembaga keuangan konvensional dan bukan hanya menjadi alternatif akan tetapi menjadi pilihan.

\section{KESIMPULAN}

a. Ekonomi syari'ah yang mengakomodir tata kelola keuangan negara seperti yang terjadi pada zaman Rasulullah. SAW yaitu BMT, maka untuk mengembangkan perekonomian islam, faktor sejarah harusnya juga menjadi pertimbangan.

b. Koperasi patut menjadi penopang perkembangan sistem ekonomi islam, karena memiliki cita-cita luhur dan tujuan yang sama dengan tujuan sistem ekonomi islam yaitu berbasis kerja sama untuk kesejahteraan bersama.

c. Koperasi ataupun BMT mampu menjadi generator untuk menjembatani tidak diakomodirnya sektor ekonomi mayoritas masyarakat oleh lembaga keuangan formal yang berbentuk BUS dan BPRS yang biasanya berbasis modal.

d. Lembaga keuangan syari'ah yang biasanya banyak menyalurkan dananya/dengan skema pembayaran balas jasa atas pembiayaan yang diterimanya bersifat tetap. Maka dengan koperasi ataupun BMT akan banyak sekali keterterapan variabilitas akad yang tersedia untuk bisnis lembaga keuangan syari'ah. Karena dengan BMT akad kerja sama akan lebih mudah dilakukan dengan dekatnya cakupan operasional yang juga akan meningkatkan pemberdayaan dan biaya kontrol yang tidak terlalu besar.

e. Moral hazard juga akan lebih mudah dikurangi karena adanya semangat kebersamaan dan kekeluargaan untuk meningkatkan kesejahteraan bersama.

f. Melindungi kepentingan kaum yang termarginalkan secara ekonomi dengan meningkatkan kesejahteraan mereka melalui kewajiban sosial dengan dana zakat, infaq dan shadaqah yang berbasis lingkungan lokal. Karena dalam penyalurannya akan lebih mudah dilakukan dengan semakin sempitnya cakupan operasional. Sehingga masalah-masalah kesenjangan kesejahteraan sosial akan lebih mudah diselesaikan dengan semakin realistisnya pemahaman atas masalah di masyarakat.

\section{DAFTAR PUSTAKA}

Al Arif, M. Nur Rianto, Euis Amalia. 2010. Teori Mikroekonomi: Suatu Perbandingan Ekonomi Islam dan Ekonomi Konvensional. Jakarta: Kencana Prenada Media Group.

Asyhadie, Zaeni. 2009. Hukum Bisnis Prinsip dan Pelaksanaannya di Indonesia. Jakarta: Rajawali Pers.

Baihaki, Ach. 2015. Analisis penerapan akuntansi syari'ah pada entitas non lembaga keuangan syari'ah. Equilibrium Vol. 4 (1 Juli 2015). 15-32.

Chapra, M. Umer. 2000. Is it necessary to have islamic economics?. The Journal of Socio-Economics 29 (2000). 21-37 
Jurnal Ilmiah Bidang Akuntansi dan Manajemen (JEMA) Vol. 14 No. 1 (2017)

http://riset.unisma.ac.id/index.php/jema

Chong, Beng Soon, Ming-Hua Liu. 2009. Islamic Banking: Interest-Free or Intersest based?. PacificBasin Finance Journal 17 (2009) 125-144

Harahap, Sofyan Syafri. 2001. Akuntansi Islam. Jakarta: Bumi Aksara.

Kamla, Rania. 2009. Critical Insights Into Contemporerary Islamic Accounting. Critical Perspective on Accounting 20 (2009). 921-932.

Muhammad. 2005. Pengantar Akuntansi Syari'ah. Jakarta. Salemba Empat.

QS. Al-Maidah ayat 2

Sakai, Minako. Growing together in partnership: Women's views of the business practices of an Islamic Savings and Credit Cooperative (Baitul Maal wat Tamwil) in Central Java, Indonesia. Women's Studies International Forum 33 (2010) 412-421

Salman, Kautsar Riza. 2012. Akuntansi Perbankan Syari'ah Berbasis PSAK Syari'ah. Jakarta: Akademia Permata.

Silondae, Arus Akbar, Andi Fariana Fathoeddin. 2013. Aspek Hukum dalam Ekonomi dan Bisnis (Edisi Revisi). Jakarta: Mitra Wacana Media.

UUD 1945 Pasal 33 ayat 1

UU No. 17 Tahun 2012 tentang perkoperasian

Yaya, Rizal. Aji Erlangga Martawireja, Ahim Abdurrahim. 2014. AKUNTANSI PERBANKAN SYARIAH Teori dan Praktik Kontemporer Edisi 2. Jakarta: Salemba Empat.

www.st2013.bps.go.id/dev/st2013/index.php/site/tabel?tid=23\&wid=0 (diakses 25 Agustus 2015)

http://pusat.baznas.go.id/wp-content/uploads/downloads/2015/06/laporan-desember-2014.pdf (diakses tanggal 3 November 2015)

http://www.ojk.go.id/data-statistik-perbankan-syariah (diakses tanggal 5 Oktober 2015)

*) Ach Baihaki, Universitas Madura 